\title{
Upper and lower gastrointestinal symptoms in HIV- infected adults in a clinical cohort in Midwestern Brazil: incidence and associated factors
}

\author{
Annelisa Silva e Alves de Carvalho Santos ${ }^{1}$ and Erika Aparecida Silveira ${ }^{2 *}$ \\ ${ }^{1}$ Professor at the United Faculty of Campinas, Goiânia, Goiás, Brazil \\ ${ }^{2}$ Post-Graduation Program in Health Sciences, Faculty of Medicine, Federal University of Goiás, Goiânia, Goiás, Brazil
}

\begin{abstract}
Aim: The present study aimed to investigate the incidence of both upper and lower gastrointestinal symptoms and associated factors in HIV-infected adults with or without antiretroviral therapy (ART). Methodology: This study is part of a clinical cohort conducted with adult HIV-infected adults in Midwestern Brazil on outpatient care. Outcome variables were the presence of upper (nausea/vomiting, dyspepsia, and heartburn) and lower (diarrhea, constipation, and flatulence) gastrointestinal symptoms incident on the week before data collection. Explanatory variables were sex, tobacco use, nutritional status, waist circumference (WC), duration of ART, protease inhibitors (PI) and non-nucleoside reverse transcriptase inhibitors (NNRTI) use, and CD4+ T lymphocyte count. The estimate of the effect was analyzed by the incidence ratio (IR) and 95\% confidence interval (CI). Statistical significance level was set at $\mathrm{p}<0.05$.

Results: Of 290 study participants, $69.0 \%$ were on ART. The most incident gastrointestinal symptom was heartburn (49.3\%), followed by flatulence (43.4\%), dyspepsia (24.5\%), nausea/vomiting (22.8), diarrhea (18.3\%), and constipation (16.2\%). No difference was observed in the incidence of gastrointestinal symptoms in participants with or without ART. The associated factors with upper and/or lower gastrointestinal symptoms were female sex, excess of body weight, abdominal obesity, less than one year of ART use, tobacco exposure, and CD4+ T lymphocyte count.

Conclusion: A high incidence of several gastrointestinal symptoms was found in HIV-infected adults, associated with both modifiable and non-modifiable risk factors. These findings contribute to gastrointestinal symptoms management in clinical practice for people living with HIV/AIDS, mainly those in risk categories, as gastrointestinal symptoms could result in adverse outcomes for this population.
\end{abstract}

\section{Introduction}

HIV-infection is a major public health problem worldwide. At the end of 2018, 37.9 million people were living with HIV, and 1.7 million people were newly infected globally [1]. Antiretroviral therapy (ART) have contributed to opportunistic infection-associated morbimortality improving the quality of life of people living with HIV/AIDS (PLWHA) significantly. However, some adverse effects may compromise treatment success $[2,3]$. Gastrointestinal symptoms are among the most common related ART adverse effects, mainly nausea, vomiting, and diarrhea [4].

The expansion of scientific knowledge on gastrointestinal symptoms in PLWHA is quite relevant, once it may result in several negative outcomes in this population, as malnutrition and micronutrient deficiency, lack to ART adherence and quality of life impairment $[5,6]$. In this context, our study aimed to estimate gastrointestinal symptoms incidence and associated factors in HIV-infected adults with and without ART.

\section{Methodology \\ The present study is part of a clinical cohort conducted in Midwestern Brazil with HIV-infected adults with or without ART on outpatient care [7-9]. The study was approved by the Institutional Ethics Committee and all study participants signed an informed consent. A trained and qualified researcher applied a structured questionnaire for data collection. After the interview, body weight, height, and}

waist circumference (WC) were measured according to standardized procedures $[10,11]$.

The investigated gastrointestinal symptoms were nausea and/or vomiting, dyspepsia, heartburn, diarrhea, constipation, and flatulence, evaluated as present or absent in the week prior the interview. We used Roma III criteria to define all gastrointestinal symptoms. Explanatory variables were sex, tobacco use, nutritional status, WC, and clinical data (time of ART, use of protease inhibitors - PI, use of non-nucleoside reverse transcriptase inhibitors - NNRTI, and CD4+ T lymphocyte count).

Tobacco use was investigated according to the Pan American Health Organization [12]. Nutritional status was classified according to Body Mass Index (BMI) ranges [11]: underweight/normal weight (BMI up to $24.9 \mathrm{~kg} / \mathrm{m}^{2}$ ), overweight (BMI $25.0-29.9 \mathrm{~kg} / \mathrm{m}^{2}$ ), and obesity (BMI

${ }^{*}$ Correspondence to: Erika Aparecida Silveira, Programa de Pós-Graduação em Ciências da Saúde, Faculdade de Medicina, Universidade Federal de Goiás (UFG), Rua 235 c/ 1 1 s s/n, Setor Universitário, CEP 74.605-020, Goiânia, Goiás, Brazil, Tel: +55 62 3209-6151; Fax: +55 62 3209-6151; E-mail: erikasil@terra.com.br

Key words: adverse effects, antiretroviral, constipation, nausea, obesity, tobacco

Received: September 30, 2019; Accepted: November 05, 2019; Published: November 08, 2019 
$\geq 30.0 \mathrm{~kg} / \mathrm{m}^{2}$ ). WC was classified as normal, increased (WC $80-88 \mathrm{~cm}$ for women and 90-94 cm for men), and abdominal obesity (WC $\geq 88$ $\mathrm{cm}$ for women and $\geq 102$ for men) [11]. Duration of ART was based on the difference from the date of the interview and the date of ART initiation informed by the study participant. CD4+ T lymphocyte count was analyzed in absolute value in cells per $\mathrm{mm}^{3}$ from the most recent count and categorized into $\leq 350$ cells $/ \mathrm{mm}^{3}$ and $>350$ cells $/ \mathrm{mm}^{3}$ WHO 2010 [13].

All statistical analysis was conducted on Stata 12.0. Absolute and relative frequency of each gastrointestinal symptom were calculated. The estimate of the effect was analyzed by the incidence ratio (IR) and $95 \%$ confidence interval (CI), considering the following reference categories: no tobacco use, no ITRNN use, underweight/normal weight, and normal WC. For the other variables, the reference category was that of lower prevalence concerning the respective gastrointestinal symptom. Statistical significance level was set at $\mathrm{p}<0.05$.

\section{Results}

Two hundred and ninety HIV-infected adults participated in the present study, mostly male $(n=226,77.9 \%)$. Participants mean age was $37.2 \pm 11.0$ years with mean $3.3 \pm 3.1$ years of HIV-infection diagnosis. About $69.0 \%$ of study participants were on ART ( $n=200$ ), being $35.9 \%$ with less than a year of ART duration. Of those on ART, all were on nucleoside reverse transcriptase inhibitors (NRTI) use; $77.7 \%$ were on NNRTI use; and 26.5\% were on PI use.

The most incident gastrointestinal symptom was heartburn (49.3\%), followed by flatulence (43.4\%), dyspepsia (24.5\%), nausea/ vomiting (22.8), diarrhea (18.3\%), and constipation (16.2\%). There was no statistical difference in the gastrointestinal symptoms' incidence regarding ART use (Table 1). The associated factors with upper and/ or lower gastrointestinal symptoms were female sex, excess of body weight, abdominal obesity, less than one year of ART use, tobacco exposure and CD4+ T lymphocyte count (Tables 2 and 3).

Table 1. Incidence of gastrointestinal symptoms by antiretroviral therapy use in HIV-infected adults $(n=290)$

\begin{tabular}{|c|c|c|c|c|}
\hline \multirow[b]{2}{*}{ Gastrointestinal Symptoms } & \multirow[b]{2}{*}{$\begin{array}{c}\text { Incidence } \\
\text { n }\left(\% ; 95 \% C I^{a}\right)\end{array}$} & \multicolumn{2}{|c|}{ Incidence } & \multirow[b]{2}{*}{ p-value ${ }^{c}$} \\
\hline & & $\begin{array}{c}\text { With ART } \\
\text { n (\%) }\end{array}$ & $\begin{array}{c}\text { Without ART }^{\mathrm{b}} \\
\text { n (\%) }\end{array}$ & \\
\hline Constipation & $47(16.21 ; 12.16-20.96)$ & $28(14.14)$ & $19(20.65)$ & 0.160 \\
\hline Diarrhea & $53(18.28 ; 14.05-23.29)$ & $41(20.81)$ & $12(13.04)$ & 0.124 \\
\hline Nausea/Vomiting & $66(22.84 ; 18.12-28.12)$ & $50(25.25)$ & $16(17.58)$ & 0.161 \\
\hline Dyspepsia & $71(24.48 ; 19.64-29.85)$ & $50(25.25)$ & $21(22.83)$ & 0.657 \\
\hline Flatulence & $126(43.45 ; 37.80-49.53)$ & $82(41.41)$ & $44(48.35)$ & 0.260 \\
\hline Heartburn & $143(49.31 ; 43.42-55.22)$ & $94(47.47)$ & $49(53.26)$ & 0.351 \\
\hline
\end{tabular}

${ }^{\mathrm{a}} 95 \% \mathrm{CI}: 95 \%$ confidence interval, ${ }^{\mathrm{b}} \mathrm{ART}$ : antiretroviral therapy, ${ }^{\mathrm{c}} \mathrm{W}$ ald test.

Table 2. Upper gastrointestinal symptoms incidence ratio by sex, tobacco use, nutritional and clinical variables in HIV-infected adults ( $\mathrm{n}=290$ )

\begin{tabular}{|c|c|c|c|}
\hline & Nausea/Vomiting & Dyspepsia & Heartburn \\
\hline & $\operatorname{IR}^{\mathrm{a}}\left(95 \% \mathrm{CI}^{\mathrm{b}}\right)$ & $\operatorname{IR}\left(95 \% \mathrm{CI}^{\mathrm{b}}\right)$ & $\operatorname{IR}\left(95 \% \mathrm{CI}^{\mathrm{b}}\right)$ \\
\hline \multicolumn{4}{|l|}{ Sex } \\
\hline Male & $\mathrm{NS}^{\mathrm{c}}$ & 1.00 & NS \\
\hline Female & NS & $2.30(1.56-3.39)$ & NS \\
\hline \multicolumn{4}{|l|}{ Tobacco use } \\
\hline No & 1.00 & NS & 1.00 \\
\hline Former smoker & $1.20(0.67-2.14)$ & NS & $0.95(0.69-1.31)$ \\
\hline Yes & $2.16(1.36-3.43)$ & NS & $1.38(1.07-1.77)$ \\
\hline \multicolumn{4}{|l|}{ Nutritional status } \\
\hline Underweight/Normal weight & NS & 1.00 & NS \\
\hline Overweight & NS & $1.69(1.08-2.63)$ & NS \\
\hline Obesity & NS & $2.43(1.25-4.71)$ & NS \\
\hline \multicolumn{4}{|l|}{ Waist circumference } \\
\hline Normal & NS & 1.00 & NS \\
\hline Increased & NS & $1.45(0.84-2.51)$ & NS \\
\hline Abdominal obesity & NS & $2.47(1.56-3.92)$ & NS \\
\hline \multicolumn{4}{|l|}{ Duration of $\mathrm{ART}^{\mathrm{d}}$} \\
\hline$<1$ year & $2.16(1.20-3.87)$ & NS & NS \\
\hline 1 to 3 years & $1.21(0.58-2.54)$ & NS & NS \\
\hline$>3$ year & 1.00 & NS & NS \\
\hline \multicolumn{4}{|l|}{$\mathbf{P I}^{\mathrm{e}}$ use } \\
\hline No & NS & NS & NS \\
\hline Yes & NS & NS & NS \\
\hline \multicolumn{4}{|l|}{ NNRTI ${ }^{\mathrm{f}}$ use } \\
\hline No & NS & NS & NS \\
\hline Yes & NS & NS & NS \\
\hline \multicolumn{4}{|l|}{ CD4+ cells count } \\
\hline$\leq 350$ cells $/ \mathrm{mm}^{3}$ & NS & NS & 1.00 \\
\hline$>350 \mathrm{cell} / \mathrm{mm}^{3}$ & NS & NS & $1.46(1.06-2.02)$ \\
\hline
\end{tabular}

${ }^{\mathrm{a}} \mathrm{IR}$ : incidence ratio, ${ }^{\mathrm{b}} 95 \% \mathrm{CI}: 95 \%$ confidence interval, ${ }^{\mathrm{c}} \mathrm{NS}$ : nonsignificant, ${ }^{\mathrm{d}} \mathrm{ART}$ : antiretroviral therapy, ${ }^{\mathrm{e} I}$ : protease inhibitors, ${ }^{\mathrm{t}} \mathrm{NNRTI}$ : non-nucleoside reverse-transcriptase inhibitors. 
Table 3. Lower gastrointestinal symptoms incidence ratio by sex, tobacco use, nutritional and clinical variables in HIV-infected adults $(\mathrm{n}=290)$

\begin{tabular}{|c|c|c|c|}
\hline & Diarrhea & Constipation & Flatulence \\
\hline & $\operatorname{IR}^{\mathrm{a}}\left(95 \% \mathrm{CI}^{\mathrm{b}}\right)$ & $\operatorname{IR}^{\mathrm{a}}\left(95 \% \mathrm{CI}^{\mathrm{b}}\right)$ & $\operatorname{IR}^{\mathrm{a}}\left(95 \% \mathrm{CI}^{\mathrm{b}}\right)$ \\
\hline \multicolumn{4}{|l|}{ Sex } \\
\hline Male & $\mathrm{NS}^{\mathrm{c}}$ & 1.00 & 1.00 \\
\hline Female & NS & $3.11(1.88-5.13)$ & $1.41(1.07-1.84)$ \\
\hline \multicolumn{4}{|l|}{ Tobacco use } \\
\hline No & NS & 1.00 & NS \\
\hline Former smoker & NS & $2.07(1.13-3.76)$ & NS \\
\hline Yes & NS & $1.44(0.73-2.82)$ & NS \\
\hline \multicolumn{4}{|l|}{ Nutritional status } \\
\hline Underweight/Normal weight & NS & NS & NS \\
\hline Overweight & NS & NS & NS \\
\hline Obesity & NS & NS & NS \\
\hline \multicolumn{4}{|l|}{ Waist circumference } \\
\hline Normal & NS & 1.00 & 1.00 \\
\hline Increased & NS & $1.28(0.58-2.82)$ & $0.94(0.63-1.39)$ \\
\hline Abdominal obesity & NS & $3.03(1.66-5.54)$ & $1.41(1.01-1.95)$ \\
\hline \multicolumn{4}{|l|}{ Duration of $\mathrm{ART}^{\mathrm{d}}$} \\
\hline$<1$ year & NS & NS & NS \\
\hline 1 to 3 years & NS & NS & NS \\
\hline$>3$ year & NS & NS & NS \\
\hline \multicolumn{4}{|l|}{$\mathbf{P I}^{\mathrm{e}}$ use } \\
\hline No & 1.00 & NS & NS \\
\hline Yes & $1.95(1.14-3.34)$ & NS & NS \\
\hline \multicolumn{4}{|l|}{ NNRTI ${ }^{\mathrm{f}}$ use } \\
\hline No & 1.00 & NS & NS \\
\hline Yes & $0.50(0.29-0.86)$ & NS & NS \\
\hline \multicolumn{4}{|l|}{ CD4+ cells count } \\
\hline$\leq 350$ cells $/ \mathrm{mm}^{3}$ & NS & NS & NS \\
\hline$>350$ cell $/ \mathrm{mm}^{3}$ & NS & NS & NS \\
\hline
\end{tabular}

aR: incidence ratio, ${ }^{\mathrm{b}} 95 \% \mathrm{CI}$ : $95 \%$ confidence interval, ${ }^{\mathrm{c} N S}$ : nonsignificant, ${ }^{\mathrm{d}} \mathrm{ART}$ :

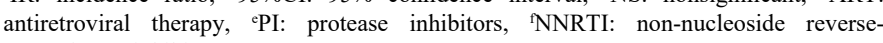
transcriptase inhibitors.

\section{Discussion}

The present study contributes to expand the scientific knowledge on gastrointestinal symptoms in PLWHA, providing relevant information for clinical care of this population. Among the associated factors are female sex, tobacco exposure, excess of body weight, abdominal obesity, duration of ART and protease inhibitors use.

Sex differences in gastrointestinal physiology may partially explain why women were more prompt to present higher incidence of gastrointestinal symptoms than men, as dyspepsia, constipation and flatulence. Intestinal motility tends to be slower in women, contributing to constipation symptoms, which could be altered due to the levels of steroid hormones, for example [14].

Regarding tobacco exposure, there are evidence of the role of nicotine toxicity and/or its byproducts in the development of several gastrointestinal disorders and diseases $[15,16]$. One of the possible mechanisms is the stimulation of parasympathetic autonomic system, increasing muscular tonus and gastrointestinal motility [17].

Abdominal obesity and excess body weight are associated with gastrointestinal complications [18], and HIV-infection may potentialize this relationship. In our study, being overweight/obese or having abdominal obesity were associated with a higher incidence of dyspepsia. In obese subjects, esophageal transit time is significantly prolonged compared with lean individuals [18], which could be due to increased gastric and gastroesophageal junction resistance [19]. Regarding constipation, abdominal obesity was an important associated factor in our study, although the relationship between obesity and constipation is not fully understood [20].

Since the beginning of HIV-infection, opportunistic infections in the gastrointestinal tract have been described, which may lead to gastrointestinal symptoms manifestation. After ART introduction, gastrointestinal symptoms caused by opportunistic infections reduced significantly. However, the use of some antiretroviral drug classes has been associated with gastrointestinal symptoms, being the most common complaints among patients on ART, primarily in its first year of use [21]. In our study this association was also observed, once nausea/vomiting were more incident in those individuals with less than a year of ART and diarrhea in those in PI use.

In conclusion, this study brings important contributions to the field of clinical management of PLWHA, mainly those in outpatient care, providing relevant information on the incidence of the most common gastrointestinal complaints in this population and the potential risk factors. Along with ART use, which is the main factor associated with gastrointestinal symptoms in PLWHA nowadays, other important factors as sex, tobacco exposure and excess of body weight and abdominal obesity may be taken into consideration when evaluating these patients in a clinical setting, directing treatment with effective strategies for each situation.

\section{Authorship and contributions}

EAS designed the research. ASACS participated in data collection. ASACS and EAS analyzed the data and wrote the paper. All authors revised the content of this manuscript and approved the final version of the paper.

\section{Acknowledgements}

To the National Council for Scientific and Technological Development $(\mathrm{CNPq})$ and the Goiás State Research Support Foundation (FAPEG) by financing the larger study. To FAPEG by granting masters scholarship to SANTOS ASAC. To the entire research team for their scientific quality and commitment to conduct all stages of the study. To OCIPD and its technical staff for all helpfulness and collaboration. To all study participants, without whom this work would not be possible.

\section{Funding}

Supported by the National Council for Scientific and Technological Development (CNPq) and the Goiás State Research Support Foundation (FAPEG).

\section{Competing interest}

None to declare.

\section{References}

1. https://www.who.int/news-room/fact-sheets/detail/hiv-aids

2. Torres TS, Cardoso SW, Velasque LS, Veloso VG, Grinsztejn B (2014) Incidence rate of modifying or discontinuing first combined antiretroviral therapy regimen due to toxicity during the first year of treatment stratified by age. Braz J Infect Dis 18: 34-41. [Crossref]

3. Li H, Marley G, Ma W, Wei C, Lackey M, et al. (2017) The role of ARV associated adverse drug reactions in influencing adherence among HIV-Infected individuals: a systematic review and qualitative meta-synthesis. AIDS Behav 21: 341-351.

4. Hill A, Balkin A (2009) Risk factors for gastrointestinal adverse events in HIV treated and untreated patients. AIDS Rev 11: 30-38.

5. Chubineh S, McGowan J (2008) Nausea and vomiting in HIV: a symptom review. Int J STD AIDS 19: 723-728. [Crossref] 
6. Li N, Spiegelman D, Drain P, Mwiru RS, Mugusi F, et al. (2012) Predictors of weight loss after HAART initiation among HIV-infected adults in Tanzania. AIDS 26: 577-585. [Crossref]

7. Nery MW, Martelli CM, Silveira EA, de Sousa CA, Falco Mde O, et al. (2013) Cardiovascular risk assessment: a comparison of the Framingham, PROCAM, and DAD equations in HIV-infected persons. ScientificWorldJournal 2013: 969281. [Crossref]

8. Santos AS, Silveira EA, Falco MO (2016) Gastrointestinal symptoms in HIV-Infected Patients: female sex and smoking as risk factors in an outpatient cohort in Brazil. PLoS One 11: e 0164774 .

9. Santos ASEAC, Silveira EAD, Falco MO, Nery MW, Turchi MD (2017) Effectiveness of nutritional treatment and synbiotic use on gastrointestinal symptoms reduction in HIV-infected patients: randomized clinical trial. Clin Nutr 36: 680-685.

10. Lohman TG, Roche AF, Martorell R (1988) Anthropometric standardization reference manual. Champaign: Human Kinetics Pub.

11. WHO (1997) Obesity: preventing and managing the global epidemic. World Health Organization, Geneva.

12. Organización Panamericana de la Salud (1997) Protocolo y directrices: conjunto de ações para la reducción multifactorial de enfermedades no transmisibles (CARMEN/ CINDI). OPAS, Washington.
13. WHO (2010) Antiretroviral therapy for HIV infection in adults and adolescents recommendations for a public health approach. World Health Organization, Geneva.

14. Freire AC, Baist AW, Choudhary R, Piong CW, Merchant HA (2011) Does sex matter? The influence of gender on gastrointestinal physiology and drug delivery. Int $J$ Pharm 415: $15-28$.

15. Chu KM, Cho CH, Shin VY (2013) Nicotine and gastrointestinal disorders: its role in ulceration and cancer development. Curr Pharm Des 19: 5-10.

16. Thomas GA, Rhodes J, Ingram JR (2005) Mechanisms of disease: nicotine--a review of its actions in the context of gastrointestinal disease. Nat Clin Pract Gastroenterol Hepatol 2: 536-544.

17. Furtado RD (2002) Smoking and anesthetic implications. Rev Bras Anestesiol 52: 354367. [Crossref]

18. Mercer CD, Rue C, Hanelin L, Hill LD (1985) Effect of obesity on esophageal transit Am J Surg 149: 177-181. [Crossref]

19. Zacchi P, Mearin F, Humbert P, Formiguera X, Malagelada JR (1991) Effect of obesity on gastroesophageal resistance to flow in man. Dig Dis Sci 36: 1473-1480. [Crossref]

20. Camilleri M, Malhi H, Acosta A (2017) Gastrointestinal complications of obesity. Gastroenterology 152: 1656-1670.

21. He M, Zheng YH, Zhou HY, Mamadou D, Chen Z, et al. (2011) Prospective observation for seven-year's highly active antiretroviral therapy in Chinese HIV-1 Infected patients. Curr HIV Res 9: 160-165.

Copyright: $\ 2019$ Santos ASAC. This is an open-access article distributed under the terms of the Creative Commons Attribution License, which permits unrestricted use, distribution, and reproduction in any medium, provided the original author and source are credited. 